\title{
Penurunan konsumsi bahan bakar pada mesin bensin 4 langkah 1 silinder dengan menggunakan medan magnet elektomagnetik
}

\section{Reduction of fuel consumption of a single-cylinder four-stroke gasoline engine by using electromagnetic field}

\section{I.M. Mara*, I.B. Alit, I.M. Nuarsa}

Jurusan Teknik Mesin, Fakultas Teknik, Universitas Mataram, Jl. Majapahit no. 62, Mataram, NTB, 83125, Indonesia.

*E-mail: made.mara@unram.ac.id

\section{ARTICLE INFO ABSTRACT}

Article History:

Received 23 September 2020

Accepted 06 March 2021

Available online 01 April 2021

\section{Keywords:}

Electromagnetic

Engine performance

Engine torque

Effective power

Fuel consumption

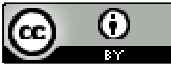

The quality of gasoline fuel is very important; therefore scientists are trying hard to improve the quality of this fuel. One of them is treating the fuel before it enters the combustion chamber or before experiencing the combustion process. The use of permanent magnets can reduce fuel consumption, and reduce exhaust emissions. This study aims to investigate the reduction of fuel consumption of a single-cylinder four-stroke gasoline engine by using electromagnetic field. Diameter and length of the copper wire used are $0.7 \mathrm{~mm}$ and 80 meters. The effect of the magnetic field on the engine performance was observed at various engine speed, such as 1500, 3000, 4500 and $6000 \mathrm{rpm}$. The results showed that the electromagnetic of solenoid winding reduced the specific fuel consumption. The percentage of reduction in the specific fuel consumption is $18.93 \%$.

Dinamika Teknik Mesin, Vol. 11, No. 1 April 2021, p. ISSN: 2088-088X, e. ISSN: 2502-1729

\section{PENDAHULUAN}

Penggunaan alat magnetasi bahan bakar sebagai salah satu upaya untuk menghemat bahan bakar semakin banyak dikembangkan oleh para peneliti. Penggunaan magnet permanen dan electromagnet sebagai alat magnetasi bahan bakar telah banyak digunakan upaya untuk melakukan penghematan bahan bakar, penurunan emisi gas buang dan meningkatkan performa dari mesin. Penggunaan magnet permanen tipe Neodymium dengan kekuatan 4000, dan 8000 Gauss yang dipasang secara langsung pada saluran bahan bakar bensin pada two-stroke engine dapat menurunkan emisi gas buang $\mathrm{CO}_{2}, \mathrm{HC}$ and $\mathrm{NO}$ berturut-turut sebesar $30,57 \%, 97 \%$ and $36,08 \%$ (Pramodkumar dkk, 2017).

Akibat adanya pengaruh medan magnet yang diberikan pada bahan bakar mesin diesel silinder tunggal empat langkah dengan putaran mesin diatur sehingga konstan pada putaran $1500 \mathrm{rpm}$ dapat menurunkan konsumsi bahan bakar sebesar 3\% pada kondisi tanpa beban dan 8,5\% pada kondisi beban maksimal. Meningkatkan persentase efisiensi termal sebesar 3,5\%, penurunan persentase emisi gas buang seperti $\mathrm{CO}_{2}$ dengan kondisi tanpa beban sebesar $5 \%$ dan dengan beban maksimal sebesar $9 \%$. Persentase emisi CO juga mengalami penurunan pada kondisi tanpa beban yaitu 
sebesar $4,5 \%$ dan $10 \%$ pada beban maksimal, serta terjadinya penurunan persentase emisi NOx sebesar $13 \%$ pada kondisi tanpa beban dan $24 \%$ pada kondisi beban maksimal (Gad, 2015).

Pada penelitian Patel dkk (2014) yang berjudul "Effect of magnetic field on performance and emission of single cylinder four stroke diesel engine" tentang efek dari medan magnet terhadap unjuk kerja dan emisi dari mesin diesel empat langkah silinder tunggal. Pada penelitiannya mereka menggunakan magnet permanen dengan kekuatan medan magnet sebesar 2000 Gauss yang dipasang di saluran bahan bakar dengan kondisi beban yang berbeda. Dengan pengaplikasian medan magnet pada saluran bahan bakar diperoleh hasil persentase penurunan konsumsi bahan bakar sebesar $8 \%$ pada beban terbesar, persentase penurunan emisi gas buang seperti $\mathrm{HC}$ dan $\mathrm{NOx}$ masing-masing sekitar $30 \%$ dan $27,7 \%$ serta penurunan emisi gas buang $\mathrm{CO}$ pada penggunaan medan magnet pada kondisi beban terbesar. Selain itu, penggunaan medan magnet dengan kekuatan 2000 Gauss juga dapat menurunkan emisi $\mathrm{CO}_{2}$ dengan persentase sebesar 9,72\% pada kondisi beban rata-rata.

Konsumsi bahan bakar mesin yang menggunakan magnet pada saluran bahan bakar lebih rendah dibandingkan dengan mesin yang tidak menggunakan medan magnet. Penggunaan medan magnet 2000, 4000, 6000 dan 8000 gauss dapat menurunkan BSFC mesin sampai 11\% pada medan magnet 6000 gauss. Dalam penelitian ini juga dilaporkan bahwa peningkatan effisiensi mekanis yang lebih baik didapat pada penggunaan medan magnet 2000 dan 4000 gauss dibandingkan dengan 6000 dan 8000 gauss (Chavan, 2016). Hasil eksperimental dari penelitian Torres, dkk (2018) juga membuktikan bahwa medan magnet menyebabkan adanya perubahan kondisi aliran bahan bakar sehingga proses pembakaran lebih optimal. Selain itu, hasil penelitian juga menunjukkan bahwa pengaruh medan magnet pada bahan bakar, lebih efisien saat magnet berada pada saluran bahan bakar daripada saat ditempatkan secara terpisah.

Pada penelitaian Mara dkk (2018) yang berjudul "analisis penggunaan alat magnetasi bahan bakar secara elektromagnetik terhadap unjuk kerja mesin empat langkah satu silinder" tentang pengaruh lilitan elektromagnetik dengan variasi lilitan yaitu 3000, 4000 dan 4500, dapat meningkatkan daya mesin sebesar $12,83 \%$ dan menurunkan $\mathrm{FC}$ sebesar $10 \%$ untuk jumlah lilitan 4000 pada putaran mesin $1500 \mathrm{rpm}$.

Namun demikian belum dijelaskan jenis atau tipe lilitan yang dipergunakan dalam membangkitkan efek magnet dalam penelitian tersebut. Untuk mengetahui pengaruh tipe lilitan elektromagnetik (solenoid dan toroid) alat magnetasi bahan bakar, dalam penelitian ini dilakukan analisis penggunaan alat magnetasi secara elektromagnetik terhadap unjuk kerja mesin bensin empat langkah satu silinder.

\section{METODE PENELITIAN}

Pada penelitian ini metode yang digunakan adalah metode eksperimen. Jenis metode penelitian ini bisa digunakan untuk menguji suatu perlakuan baru dengan membandingkan satu atau lebih kelompok pengujian dengan dan tanpa perlakuan. Adapun tahapan dalam pelaksanaan yang digunakan dalam penelitian ini meliputi tahap persiapan, tahan pengujian dan pengambilan data, dan tahap analisa data.

Dalam tahap persiapan dilakukan studi pustaka, pengadaan bahan dan peralatan. Selanjutnya dilakukan pengujian unjuk kerja dari alat yang telah dibuat dengan variasi medan magnet elektromagnetik yang dibuat secara solenoid dan toroid dengan diameter kawat tembaga $0,7 \mathrm{~mm}$ dan panjang area magnetasi $45 \mathrm{~mm}$ dan panjang kawat $80 \mathrm{~m}$. Variasi putaran mesin $1500 \mathrm{rpm}, 3000 \mathrm{rpm}$, $4500 \mathrm{rpm}$, dan $6000 \mathrm{rpm}$. Sumber arus medan magnet yang digunakan diambil dari baterai dengan tegangan 12 volt dan arus yang mengalir pada lilitan adalah sebesar 3,01 A. Besar medan magnet yang dihasilkan pada lilitan solenoid adalah 414 gauss dan pada lilitan toroid adalah 463 gauss. Pada tahap pengujian dilakukan pengambilan data konsumsi bahan bakar dan gaya pengereman, kemudian dari data tersebut dilakukan perhitungan untuk mengetahui besar torsi, daya efektif dan konsumsi bahan bakar pada mesin uji. Dalam tahap analisa dilakukan perhitungan-perhitungan untuk mengetahui hubungan antara putaran dengan torsi, daya efektif, dan konsumsi bahan bakar baik pada kondisi dengan dan tanpa pemasangan alat magnetasi bahan bakar. Unjuk kerja mesin akan dibandingkan antara penggunaan alat magnetasi lilitan solenoid dengan toroid dan dengan kondisi mesin standar (tanpa penggunaan alat magnetasi).

Rancangan alat magnetasi bahan bakar dibuat seperti gambar 1. berikut ini. 


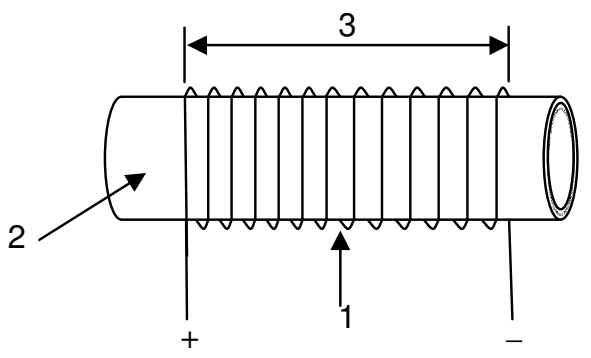

(a)

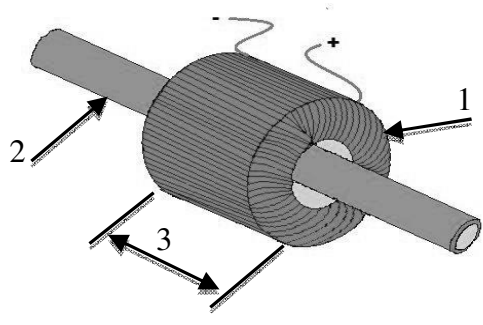

(b)

Gambar 1. (a).Lilitan solenoid, (b). lilitan toroid. 1. kawat kumparan, 2. saluran bahan bakar, 3. panjang lilitan

Sedangkan skema susunan alat uji ditunjukkan dalam gambar 2 berikut ini

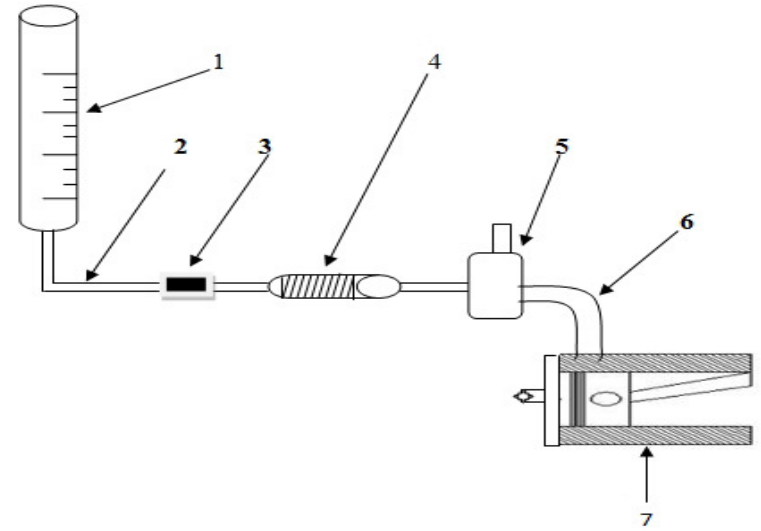

Gambar 2. Skema alat uji. 1. gelas ukur, 2. saluran bahan bakar, 3. saringan bahan bakar, 4. alat magnetasi bahan bakar, 5. karburator, 6. intake manifold, 7. ruang bakar mesin.

\section{HASIL DAN PEMBAHASAN}

Nilai torsi yang dihasilkan oleh mesin uji dapat dihitung dengan mengalikan besarnya gaya pengereman dengan jari-jari alat ukur torsi (Job, 2018). Jika T adalah torsi (N.m), F merupakan gaya pengereman $(\mathrm{N})$, dan $\mathrm{r}$ adalah radius gaya yang bekerja, maka torsi mesin dapat dihitung sebagai berikut.

$T-F_{i}$

Hasil rata-rata nilai torsi hasil perhitungan ditampilkan dalam table 1 berikut ini.

Table 1. Data rata-rata hasil perhitungan torsi (N.m)

\begin{tabular}{llll}
\hline Putaran mesin(Rpm) & Standar & Solenoid & Toroid \\
\hline 1500 & 0,66 & 1,07 & 0,86 \\
3000 & 6,89 & 7,09 & 6,92 \\
4500 & 7,13 & 7,26 & 7,14 \\
6000 & 7,24 & 7,39 & 7,32 \\
\hline
\end{tabular}

Data hasil perhitungan torsi yang diperoleh kemudian dibuat grafik hubungan antara torsi dengan putaran mesin. 
Dinamika Teknik Mesin. Mara dkk.: Penurunan konsumsi bahan bakar pada mesin bensin 4 langkah 1 silinder dengan menggunakan medan magnet elektomagnetik

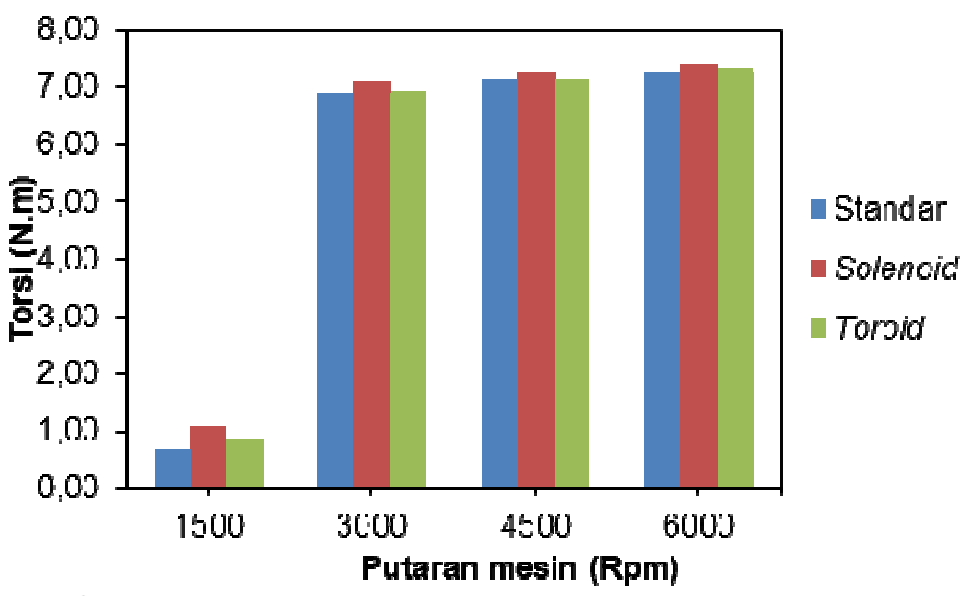

Gambar 3. Hubungan torsi terhadap putaran mesin

Berdasarkan gambar 3 pengaruh torsi terhadap putaran mesin, dapat diketahui bahwa torsi yang dihasilkan meningkat seiring dengan meningkatnya putaran mesin. Torsi yang dihasilkan melalui pembakaran bahan bakar semakin meningkat, dikarenakan jumlah bahan bakar yang masuk ke dalam ruang bakar bertambah seiring dengan meningkatnya putaran mesin. Semakin tinggi putaran maka torsi semakin meningkat. Selain dari itu, torsi yang dihasilkan pada pengujian mesin yang mengunakan alat magnetasi bahan bakar menunjukan hasil yang sedikit lebih tinggi jika dibandingkan dengan percobaan tanpa menggunakan alat magnetasi pada saluran bahan bakar untuk setiap variasi putaran mesin. Hal ini terjadi karena bahan bakar yang terkena pengaruh medan magnet menjadi lebih mudah dalam mengikat oksigen (campuran bahan bakar dengan oksigen lebih baik) yang menyebabkan proses pembakaran akan lebih baik. Proses pembakaran yang lebih baik ini akan menghasilkan torsi yang lebih baik. Pada putaran 1500 tidak terjadi perubahan torsi yang menonjol, kenaikan torsi mulai terlihat pada putaran 3000 rpm untuk masing-masing tipe lilitan elektromagnetik alat magnetasi bahan bakar, kenaikan torsi yang terjadi pada putaran $3000 \mathrm{rpm}$ untuk masing-masing tipe lilitan elektromagnetik yaitu sebesar $2,9 \%$ pada tipe solenoid dan $0,43 \%$ pada tipe toroid. Pada putaran $4500 \mathrm{rpm}$ kenaikan torsi yang terjadi pada masing-masing tipe lilitan elektromagnetik yaitu sebesar $1,8 \%$ pada tipe lilitan solenoid dan $0,14 \%$ pada tipe lilitan toroid. Sedangkan pada putaran mesin sebesar $6000 \mathrm{rpm}$, kenaikan torsi yang terjadi pada masing-masing tipe lilitan elektromagnetik yaitu sebesar $2,07 \%$ pada tipe lilitan solenoid dan sebesar $1,1 \%$ pada tipe lilitan toroid. Dari kedua tipe lilitan elektromagnetik alat magnetasi bahan bakar, persentase kenaikan torsi sedikit lebih tinggi pada medan magnet lilitan solenoid dibandingkan dengan toroid. Hal ini sejalan dengan hasil penelitian Chavan, 2016, namun peningkatan nilai torsi mesin pada penelitian ini masih sangat kecil.

Besar nilai daya efektif $(\mathrm{Ne})$ tergantung dari besarnya torsi dan putaran mesin. Hal ini dapat dilihat pada persamaan berikut (Mara dkk, 2018).

$\mathrm{Ne}=\frac{2 \pi T \pi}{1000}(\mathrm{~kW})$

Dengan Ne adalah daya efektif (kW), dan $\mathrm{n}$ adalah putaran mesin per detik (rps).

Table 2. Data rata-rata hasil perhitungan daya efektif $(\mathrm{kW})$

\begin{tabular}{llll}
\hline Putaran mesin $(\mathrm{Rpm})$ & Standar & Solenoid & Toroid \\
\hline 1500 & 0,10 & 0,17 & 0,14 \\
3000 & 2,16 & 2,23 & 2,17 \\
4500 & 3,36 & 3,42 & 3,36 \\
6000 & 4,55 & 4,64 & 4,60 \\
\hline
\end{tabular}

Dari data hasil perhitungan daya efektif yang diperoleh kemudian dibuat sebuah grafik hubungan antara daya efektif dengan putaran mesin. 
Dinamika Teknik Mesin. Mara dkk.: Penurunan konsumsi bahan bakar pada mesin bensin 4 langkah 1 silinder dengan menggunakan medan magnet elektomagnetik

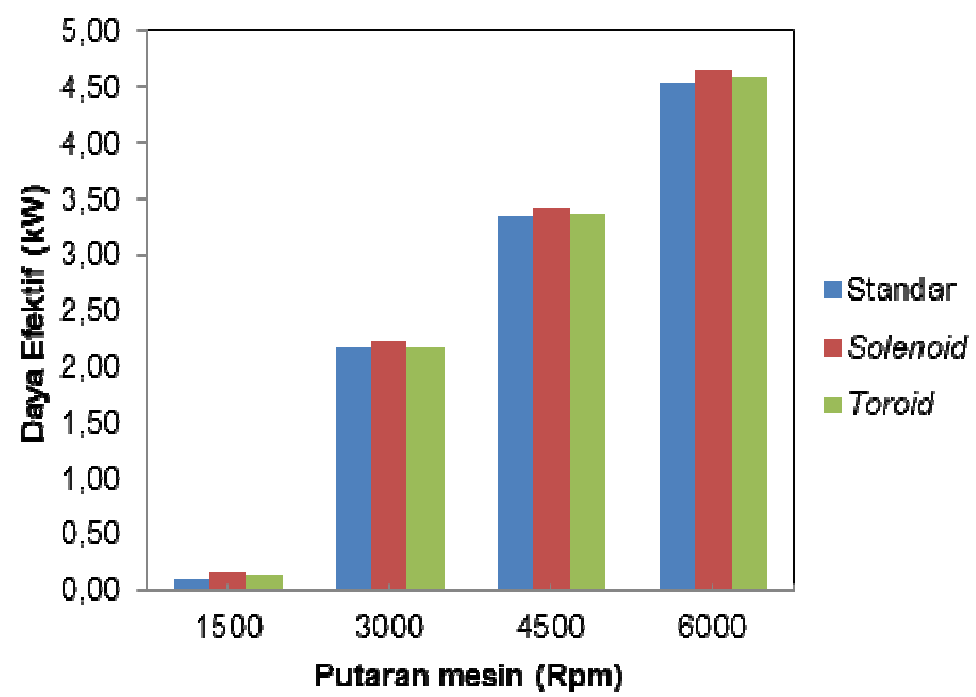

Gambar 4. Hubungan daya efektif terhadap putaran mesin.

Berdasarkan gambar 4 terlihat bahwa daya efektif yang dihasilkan pada mesin meningkat seiring dengan meningkatnya putaran mesin. Hal ini dikarenakan meningkatnya putaran mesin meningkatkan jumlah pembakaran bahan bakar yang terjadi pada ruang bakar. Pada putaran mesin yang lebih tinggi akan membutuhkan volume bahan bakar yang masuk ke ruang bakar lebih banyak sehingga energi yang dihasilkan melalui pembakaran akan semakin besar.

Selain putaran mesin yang dapat mempengaruhi daya yang dihasilkan pada mesin, torsi juga akan berpengaruh artinya semakin besar torsi yang dihasilkan pada mesin maka daya pada mesin juga akan semakin besar. Pada putaran terendah yaitu pada putaran $1500 \mathrm{rpm}$ perubahan daya antara percobaan tanpa pengunaan alat magnetasi bahan bakar dan dengan penggunaan alat magnetasi bahan bakar menunjukan hampir tidak adanya perubahan daya yang menonjol. Pada putaran $3000 \mathrm{rpm}$ kenaikan daya efektif pada masing-masing percobaan sangat kecil pada masingmasing tipe lilitan elektromagnetik alat magnetasi bahan bakar yaitu sebesar 2,23 kW pada tipe lilitan solenoid dan sebesar $2,17 \mathrm{~kW}$ pada tipe lilitan toroid. Pada putaran mesin $4500 \mathrm{rpm}$ daya efektif yang dihasilkan pada masing-masing tipe lilitan elektromagnetik yaitu sebesar $3.42 \mathrm{~kW}$ pada tipe lilitan solenoid dan besar daya efektif yang dihasilkan pada tipe lilitan toroid yaitu sebesar 3,36 kW. Sedangkan untuk putaran mesin sebesar $6000 \mathrm{rpm}$ daya efektif yang dihasilkan pada mesin dari masing-masing tipe lilitan elektrimagnetik alat magnetasi bahan bakar adalah sebesar 4,64 kW pada tipe lilitan solenoid dan untuk tipe lilitan toroid daya efektif yang dihasilkan adalah sebesar 4,60 kW.

Dari gambar 4 di atas diperoleh daya efektif yang tertinggi dihasilkan pada medan magnet lilitan solenoid yaitu sebesar $4,64 \mathrm{~kW}$, daya efektif yang terendah dihasilkan dengan tanpa penggunaan alat magnetasi bahan bakar yaitu sebesar $4,55 \mathrm{~kW}$ pada putaran $6000 \mathrm{rpm}$, dengan persentase kenaikan daya efektif yang dihasilkan antara penggunaan alat magnetasi bahan bakar dengan medan magnet solenoid dengan tanpa penggunaan alat magnetasi adalah sebesar $2,01 \%$. Kenaikan yang terjadi antara penggunaan alat magnetasi dengan medan magnet lilitan toroid dengan tanpa penggunaan alat magnetasi mengalami kenaikan sebesar 1,13\%. Penggunaan medan magnet secara elektromagnetik pada saluran bahan bakar dapat sedikit meningkatkan daya efektif dibandingkan dengan tanpa penggunaan medan magnet hal ini dimungkinkan akibat medan magnet dapat mempengaruhi bahan bakar agar lebih reaktif mengikat oksigen (Firmansyah dan Sudarmanta, 2016), sehingga campuran bahan bakar dengan oksigen terjadi lebih baik akan meningkatkan kualitas pembakaran yang pada akhirnya meningkatkan daya mesin (Mara dkk, 2018), namun peningkatan daya efektif yang terjadi masih sangat kecil.

Konsumsi bahan bakar merupakan ukuran pemakaian bahan bakar dalam periode waktu tertentu yang biasanya diukur dalam satuan berat bahan bakar persatuan waktu. Besarnya konsumsi bahan bakar (FC) dapat dihitung menggunakan persamaan berikut (Mara dkk, 2018).

$F C=\frac{W}{f} \rho \frac{360}{10^{4}} \quad(\mathrm{~kg} / \mathrm{jam})$ 
Dinamika Teknik Mesin. Mara dkk.: Penurunan konsumsi bahan bakar pada mesin bensin 4 langkah 1 silinder dengan menggunakan medan magnet elektomagnetik

Dengan FC adalah fuel consumption (kg/jam), Vf menyatakan volume bahan bakar (ml), dan $\mathrm{t}$ adalah waktu (detik) dan $\rho$ adalah massa jenis bahan bakar $\left(\mathrm{kg} / \mathrm{m}^{3}\right)$.

Table 3. Data rata-rata hasil perhitungan fuel consumption ( $\mathrm{kg} / \mathrm{jam})$.

\begin{tabular}{llll}
\hline Putaran mesin(Rpm) & Standar & Solenoid & Toroid \\
\hline 1500 & 0,20 & 0,17 & 0,19 \\
3000 & 0,55 & 0,48 & 0,54 \\
4500 & 0,75 & 0,62 & 0,68 \\
6000 & 1,02 & 0,85 & 0,93 \\
\hline
\end{tabular}

Selanjutnya specific fuel consumption effective (SFCe) dalam satuan (kg/kW.jam), FC adalah fuel consumption dalam kg/jam sedangkan Ne merupakan daya mesin dalam DK maka SFCe dapat ditentukan dengan persamaan berikut (Mara dkk, 2018).

$S F C=-\frac{F C}{N g}(\mathrm{~kg} / \mathrm{jam} . \mathrm{kW})$

SFCe sebagai parameter yang digunakan untuk mengukur tingkat ekonomi penggunaan bahan bakar yang dipakai per jam untuk setiap daya yang dihasilkan oleh mesin. Semakin rendah harga SFCe menyatakan efisiensi yang semakin tinggi.

Table 4. Data rata-rata hasil perhitungan specific fuel consumption effective (kg/kW.jam).

\begin{tabular}{llll}
\hline Putaran mesin(Rpm) & Standar & Solenoid & Toroid \\
\hline 1500 & 1,93 & 1,06 & 1,39 \\
3000 & 0,25 & 0,21 & 0,25 \\
4500 & 0,22 & 0,18 & 0,20 \\
6000 & 0,23 & 0,18 & 0,20 \\
\hline
\end{tabular}

Dari data perhitungan konsumsi bahan bakar (FC) dan specific fuel consumption effective (SFCe) dapat dibuat grafik hubungan antara konsumsi bahan bakar efektif dengan putaran mesin.

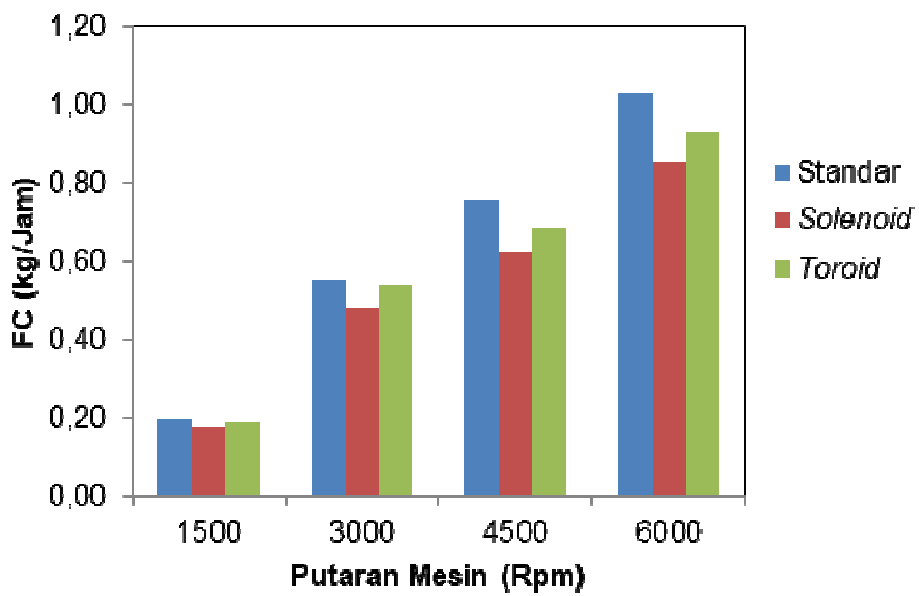

Gambar 5. Hubungan konsumsi bahan bakar terhadap putaran mesin.

Dari gambar 5 di atas menunjukkan pengaruh putaran mesin terhadap konsumsi bahan bakar, di mana semakin tinggi putaran mesin maka akan semakin banyak volume bahan bakar yang dibutuhkan untuk proses pembakaran pada ruang bakar. Pada gambar 5 di atas terlihat bahwa pada percobaan yang menggunakan alat magnetasi bahan bakar secara elektromagnetik mengalami penghematan konsumsi bahan bakar dibandingkan dengan tanpa penggunaan alat magnetasi bahan bakar. Pada percobaan penggunaan alat magnetasi bahan bakar dengan penggunaan tipe lilitan solenoid memberikan penghematan konsumsi bahan bakar sebesar $17,51 \%$ pada putaran $4500 \mathrm{rpm}$. Sedangkan pada penggunaan alat magnetasi bahan bakar dengan penggunaan tipe toroid memberi penghematan konsumsi bahan bakar sebesar $9,26 \%$ pada putaran mesin $4500 \mathrm{rpm}$. Pada percobaan 
dengan variasi putaran $6000 \mathrm{rpm}$ tanpa penggunaan alat magnetasi bahan bakar konsumsi bahan bakar adalah sebesar $1,02 \mathrm{~kg} / \mathrm{jam}$. Pada penggunaan alat magnetasi bahan pada putaran mesin 6000 rpm memberi penurunan konsumsi bahan bakar sebesar $16,80 \%$ pada penggunaan tipe lilitan solenoid dan pada penggunaan tipe lilitan toroid memberi penghematan bahan bakar sebesar $9,62 \%$ pada putaran mesin yang sama. Hal ini menunjukan bahwa pemasangan medan magnet elektromagnetik dapat menurunkan konsumsi bahan bakar yang masuk pada ruang bakar. Hal ini juga mengidentifikasikan bahwa pemberian medan magnet pada bahan bakar tersebut berpengaruh terhadap konsumsi bahan bakar di setiap putaran mesin (Torres dkk, 2018). Medan magnet yang ditempatkan pada saluran bahan bakar dapat mempengaruhi bahan bakar agar lebih cepat dan reaktif mengikat oksigen sehingga proses pembakaran di dalam silinder akan menjadi lebih baik dengan demikian jumlah bahan bakar yang dibakar menjadi lebih sedikit pada putaran mesin yang sama.

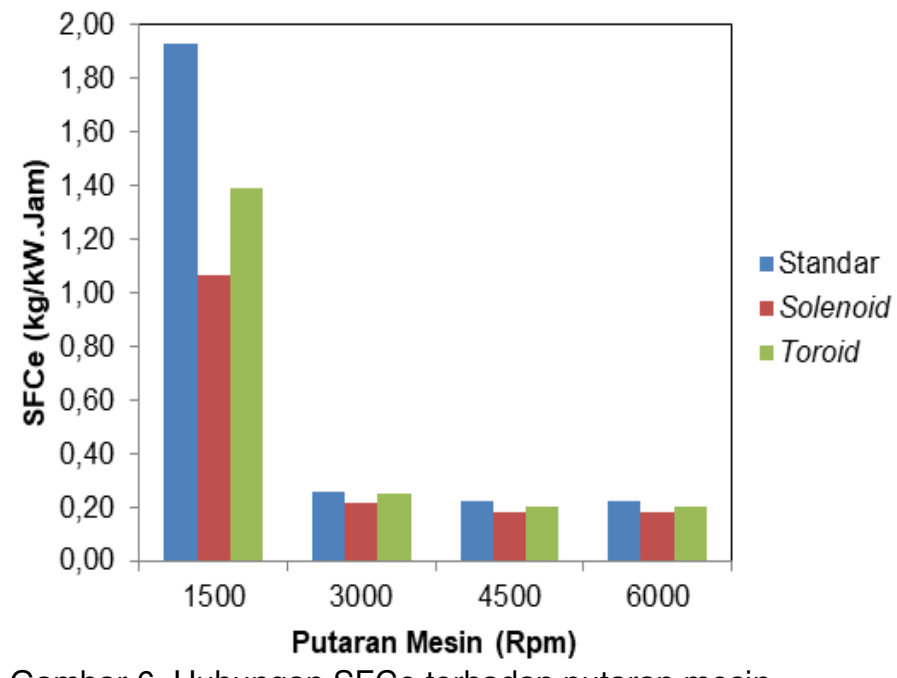

Gambar 6. Hubungan SFCe terhadap putaran mesin.

Pada gambar 6 menunjukan semakin tinggi putaran mesin maka SFCe yang dihasilkan semakin rendah, ini menunjukan semakin rendahnya nilai SFCe yang dihasilkan maka tingkat efisiensi penggunaan bahan bakar yang semakin baik. Nilai SFCe yang terendah dihasilkan pada percobaan tanpa penggunaan medan magnet yaitu sebesar $0,22 \mathrm{~kg} / \mathrm{kW}$.jam pada putaran mesin $4500 \mathrm{rpm}$. Sementara nilai SFCe terendah dihasilkan pada penggunaan medan magnet elektromagnetik didapat pada medan magnet Solenoid yaitu sebesar $0,18 \mathrm{~kg} / \mathrm{kW}$.jam pada putaran mesin sebesar 4500 dan $6000 \mathrm{rpm}$. Persentase penurunan nilai SFCe yaitu sebesar 18,93\% untuk medan magnet dari lilitan solenoid dan sebesar 9,37\% untuk medan magnet lilitan toroid pada putaran $4500 \mathrm{rpm}$.

Gambar 6 di atas juga menunjukan terjadinya perubahan SFCe yang besar pada putaran 1500 rpm antara tanpa penggunan alat magnetasi dengan penggunaan alat magnetasi. Besar nilai SFCe tanpa penggunaan alat magnetasi bahan bakar adalah sebesar $1,93 \mathrm{~kg} / \mathrm{kW}$.jam, nilai SFCe untuk penggunaan medan magnet lilitan solenoid yaitu sebesar $1,06 \mathrm{~kg} / \mathrm{kW}$.jam dan besar nilai SFCe untuk penggunaan medan magent lilitan toroid adalah $1,39 \mathrm{~kg} / \mathrm{kW}$.jam pada putaran mesin yang sama yaitu $1500 \mathrm{rpm}$. Terjadinya penurunan tingkat konsumsi bahan kabar spesifik dengan penggunaan medan magnet pada saluran bahan bakar, hal ini dikarenakan terjadinya proses pembakaran yang lebih baik dibandingkan dengan tanpa penggunaan medan magnet sehingga menurunkan nilai SFCe. Hal senada juga diungkap pada Firmansyah dan Sudarmanta (2016) bahwa medan magnet pada saluran bahan bakar dapat menurunkan nilai SFCe pada semua putaran mesin.

\section{KESIMPULAN}

Berdasarkan hasil penelitian yang telah dilakukan analisa data dan pembahasan dapat ditarik kesimpulan sebagai berikut yaitu bahwa medan magnet elektromagnetik yang ditempatkan pada saluran bahan bakar berpengaruh terhadap penurunan konsumsi bahan bakar yang dihasilkan pada mesin jika dibandingkan dengan tanpa penggunaan alat magnetasi bahan bakar atau kondisi standar. Konsumsi bahan bakar terendah diperoleh pada penggunaan medan magnet dari lilitan solenoid yaitu sebesar $0,17 \mathrm{~kg} / \mathrm{jam}$ pada putaran mesin $1500 \mathrm{rpm}$. Prosentase tertinggi penurunan konsumsi bahan bakar yang terjadi pada penggunaan medan magnet dari lilitan solenoid adalah sebesar $17,51 \%$ pada putaran $4500 \mathrm{rpm}$. SFCe terendah terjadi pada penggunaan medan magnet dari lilitan solenoid yaitu 
Dinamika Teknik Mesin. Mara dkk.: Penurunan konsumsi bahan bakar pada mesin bensin 4 langkah 1 silinder dengan menggunakan medan magnet elektomagnetik

sebesar $0,18 \mathrm{~kg} / \mathrm{kW}$.jam yang didapat pada putaran 4500 dan $6000 \mathrm{rpm}$. Prosentase penurunan SFCe yaitu sebesar $18,93 \%$ dengan penggunaan medan magnet dari lilitan solenoid pada putaran mesin $4500 \mathrm{rpm}$.

\section{UCAPAN TERIMAKASIH}

Penulis pada kesempatan ini mengucapkan terimakasih kepada semua pihak yang telah membantu baik berupa materi maupun pikiran sehingga penelitian dan paper ini dapat terselesaikan. Penulis juga mengapresiasi Jurusan Teknik Mesin Fakultas Teknik Universitas Mataram atas fasilitas yang dipergunakan dalam penelitian ini.

\section{DAFTAR NOTASI}

$\mathrm{F} \quad$ : Gaya pengereman $(\mathrm{N})$

FC : Fuel consumption $(\mathrm{kg} / \mathrm{jam})$

$\mathrm{N} \quad$ : Putaran mesin (rpm)

$\mathrm{N} \quad$ : Putaran mesin per detik

$\mathrm{Ne} \quad$ : Daya efektif (DK)

$r \quad$ : Radius gaya yang bekerja $(\mathrm{m})$

T : :Torsi (N.m)

t : : Waktu (detik)

Vf : Volume pemakaian bahan bakar $(\mathrm{ml})$

$\rho \quad$ : Massa jenis $\left(\mathrm{kg} / \mathrm{m}^{3}\right)$

\section{DAFTAR PUSTAKA}

Chavan S., 2016, Effects of Application of magnetic field on efficiency of petrol engine, International Research Journal of Engineering and Technology (IRJET), 03(9), 152-161.

Firmansyah A, Sudarmanta B., 2016, Pengaruh pemberian induksi magnet pada aliran bahan bakar terhadap penyerapan radiasi infra merah molekul hidrokarbon dan unjuk kerja mesin sinjai 650 Cc 2 silinder (studi kasus : sumber tegangan listrik dari alternator), JURNAL TEKNIK ITS, 4(1), $1-6$.

Gad M.S., 2015, Performance and exhaust emissions of a diesel engine burning magnetized fuel, GEInternational Journal of Engineering Research, 3(9), 13-21.

Job M., 2018, Measurements of energy Quantities, Lecture and Laboratory, IMIUE.

Mara I.M., Joniarta I.W., Alit I.B., Sayoga I.M.A., Nuarsa I.M., 2018, Analisis penggunaan alat magnetasi bahan bakar secara elektromagnetik terhadap unjuk kerja mesin empat langkah satu silinder, Dinamika Teknik Mesin,8(2), 98-103.

Pramodkumar G., Naidu M.K., Sandeep J.V., Ramu V., Praveen L., 2017, Effect of magnetic field on the emissions of single cylinder four stroke petrol engine, advances in automobile engineering, 6(4), 1-4.

Patel P.M., Rathod G.P., Patel T.M., 2014, Effect of magnetic field on performance and emission of single cylinder four stroke diesel engine, IOSR Journal of Engineering, 4(5), 28-34.

Torres R.G., Mehrvar M., 2018, An experimental evidence of gasoline ionization by a magnetic field, Proceedings of the 2nd International Conference of Recent Trends in Environmental Science and Engineering (RTESE'18), Niagara Falls, Canada, 44-1 - 144-8. 